\title{
PROBLEM OF UNEVEN ECONOMIC DEVELOPMENT OF THE WORLD ECONOMY: ESSENCE AND CAUSES
}

\author{
Khrystyna KYRYLYCH \\ Ivan Franko National University of Lviv, Ukraine, \\ Department of International Relations \\ Sichovykh Striltciv Str., 19, 79000, Lviv, Ukraine \\ Phone: +380685008489 \\ E-mail: kh_kyrylych@ukr.net \\ doi:10.13165/IE-13-7-3-06
}

\begin{abstract}
The paper looks at the problem of uneven economic development in terms of processes of globalisation and integration and analyses current issues and prospects. The problem is analysed retrospectively to estimate the reasons of global unevenness. The findings are used to determine the current situation on the global economic arena and answer the question why some countries are rich and others are poor. It is stressed that that legacy of colonialism in the world is the primary reason of uneven economic development. Yet, the industrial revolutions, globalisation and regionalisation of trade had an impact on the current division of the world into "North and South".
\end{abstract}

JEL classification: F02, F54, F59.

Keywords: uneven economic development, colonialism, globalisation, industrial revolution, North-South, regionalisation of trade.

Reikšminiai žodžiai: netolygus ekonomikos augimas, globalizacija, regionalizacija, pasaulio pasidalijimas.

\section{Introduction}

International economic relations are the result of the division of labour and are naturally characterised by dominants which determine economic realities. Recent decades, carrying a qualitative change through the prism of globalisation, are characterised by the intensification of trade, investment and information flows, on the one hand, and their concentration in the hands of post-industrial countries, on the other. This causes the need for scientific evidence of uneven economic development of the global economy. Over the last years, the problem of uneven economic development became an urgent issue of international economy [1-6, 10, 12].

Asymmetric level of global economic development requires a qualitatively new understanding of the concept of global development, as integration associations are 
becoming more and more significant, which prevents from considering the states as individual players on the world arena. Therefore, the characteristic feature of the globalised economy of the twenty-first century is the economy of "group against the group." Qualitative and quantitative changes of parameters in the system of international economic relations lead to the consideration of economic development as a set of interrelated socio-economic, political, institutional, financial and legal norms.

Yet, economic inequality is inherent in the dynamically changing economic system of free entrepreneurship and has some natural character, based upon the multilevel potential of different regions. Realities of modern economic globalisation lead to rethinking of scientific imbalances in the world economy through the prism of international proportions. Paradoxically, the modern world is not characterised by uniformity but rather polarisation and marginalisation, where the main commercial, financial and investment flows are concentrated in the hands of economically developed countries. Therefore, under these conditions it is necessary, yet in the light of national identity and the processes of stabilisation and recovery, to overestimate the problem of formation and development of the world market, taking globalisation challenges into account. Therefore, a definition of the essence and causes of the problem of uneven economic development is important.

\section{The Essence of Uneven Economic Development}

Uneven development is an essential feature of the capitalist economy, which reflects the tendency to focus growth and investment in certain regions [10]. The advantages of these regions can be defined with the help of specific set of factors: geographical location, resource potential and the potential of labour force, availability of capital and so on. Concentration of growth in a certain region leads to increased investment, labour and resources from the surrounding regions, which subsequently act as a secondary supply of resources and labour force in the area of economic prosperity.

There are different geographic levels of human activity: global, macroregional (e. g. EU, North America, East Asia), national (which create international, transnational and supranational connections), regional (e. g. California, North East England), local (e. g. Silicon Valley, City of London), workplace [10]. Yet, in this paper we will focus on the global level of human activity.

On a global scale, the essence of unevenness is in the relationship and interactions between the centre, the USA, Japan, the EU and the periphery, the "Global South" - some countries in Asia, Latin America and Africa.

The colonial heritage might be defined as the main reason for uneven economic development at global level, as the consequences of colonialism are felt particularly acutely under conditions of high interdependence of global economy. Different levels of functioning of institutional mechanisms in metropolises and colonies, as well as economic exploitation is one of the sources for differentiating the levels of economic development, and the distribution of forces and influences between the nineteenth and early twentieth century is still an issue (Table 1) [7]. 
Table 1. Division of the world between the states between the late nineteenth and early twentieth century (million)

\begin{tabular}{|l|c|c|c|c|c|c|c|c|}
\hline \multirow{2}{*}{ States } & \multicolumn{4}{|c|}{ Colonies } & \multicolumn{2}{c|}{ Metropolis } & \multicolumn{2}{c|}{ Totally } \\
\cline { 2 - 10 } & \multicolumn{2}{|c|}{$\mathbf{1 8 7 6}$} & \multicolumn{2}{c|}{$\mathbf{1 9 1 4}$} & \multicolumn{2}{c|}{$\mathbf{1 9 1 4}$} & \multicolumn{2}{c|}{} \\
\cline { 2 - 9 } & $\mathrm{km}^{2}$ & pop. & $\mathrm{km}^{2}$ & pop. & $\mathrm{km}^{2}$ & pop. & $\mathrm{km}^{2}$ & pop. \\
\hline England & 22.5 & 251.9 & 33.5 & 393.5 & 0.3 & 46.5 & 33.8 & 440 \\
\hline Russia & 1.7 & 15.9 & 17.4 & 33.2 & 5.4 & 136.2 & 22.8 & 169.4 \\
\hline France & 0.9 & 6 & 10.6 & 55.5 & 0.5 & 39.9 & 1.1 & 95.1 \\
\hline Germany & - & - & 2.9 & 12.3 & 0.5 & 64.9 & 3.4 & 77.2 \\
\hline Japan & - & - & 0.3 & 19.2 & 0.4 & 53.0 & 0.7 & 72.2 \\
\hline USA & - & - & 0.3 & 9.7 & 9.4 & 97 & 9.7 & 106.7 \\
\hline Together & 40.4 & 273.8 & 65 & 523.4 & 19.5 & 437.2 & 81.5 & 960.6 \\
\hline Colonies of other states & - & - & 9.9 & 45.3 & - & - & 9.9 & 45.3 \\
\hline $\begin{array}{l}\text { "Semi-colonies" } \\
\text { (Turkey, China, Persia) }\end{array}$ & - & - & - & - & - & - & 14.5 & 361.2 \\
\hline Other states of the world & - & - & - & - & - & - & 28 & 289.9 \\
\hline World & - & - & - & - & - & - & 133.9 & 1657 \\
\hline
\end{tabular}

Source [9].

In the process of multistage and multilevel evolution of trade relations between the countries of the world it is possible to allocate three stages of economic globalisation, namely the periods of 1870-1914, 1945-1970, and 1970 - until present. A retrospective analysis of global poverty from 1820 offered by F. Bourguignon and C. Morrisson suggests reducing extreme poverty from 1980, where "poverty" means living on less than $2 \$$ per day, and "extreme poverty" - on $1 \$$ per day (1985 PPP dollar). In turn, the number of "poor" population of the planet has increased from 1 billion in 1820 to 2.8 billion in 1992 (Fig. 1) [1].

Figure 1. Evolution of global poverty during 1820-1992 (millions of persons)

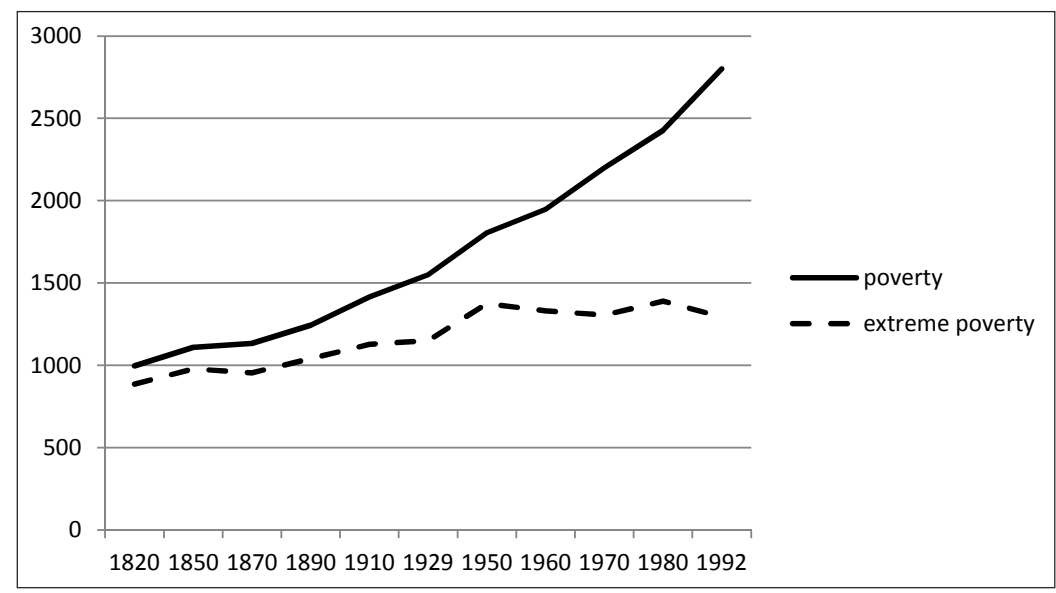

Source [2]. 
Uneven economic development of the world economy has become clear in the nineteenth century, when the West achieved sharp economic breakthrough on the basis of which a group of developing countries was formed. The industrial revolution in England, which later spread to other European countries, Japan and the U.S., and improvement of financial, banking, institutional and agricultural areas have become the causes of a breakthrough, while developing countries are characterised by the absence of all of the above factors. The global economic system has been formed on the basis of the expansion of European capital, where nineteenth century was a transitional period between the two waves of colonial expansion, namely the twentieth century and the early fifteenth century (with the end of the Second World War). The second wave of colonial expansion coincides with the first wave of modern globalisation. Therefore, the early twentieth century has consolidated the dominance of the West in the political, economic, military and cultural fields and colonial heritage defines the current state of the world economy where a huge gap between the economic development of countries is clear (Fig.2) [5].

Figure 2. Dynamics of GDP per capita of the major regions of the world during 1000-1998 (1990 international dollars)

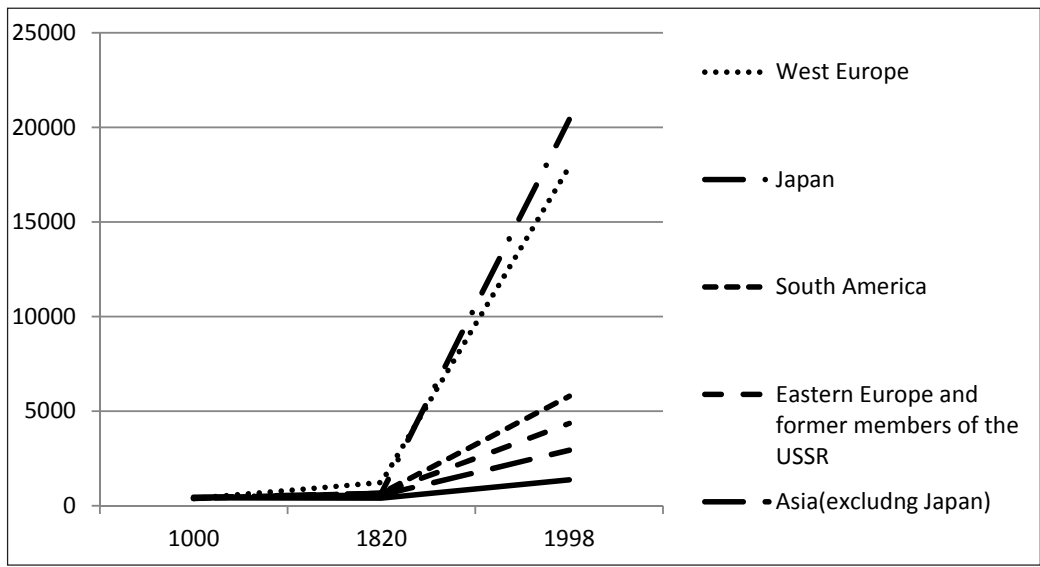

Source [11].

Therefore, according to our definition, uneven economic development is a special development process inherent in today's globalised world economy, the specifics of which are deep divergences between countries in all spheres of social and economic life, accompanied by uneven distribution of benefits from globalisation and increasing gap in income levels on a planetary scale. 


\section{Historical Patterns}

Key parameters of the modern world economy were formed on the basis of past colonial relationship, since international trade was the foundation of economic growth in Western Europe, unlike Africa or Asia. Thus, during the period of 1000-1500 European trade was based on sea routes between Venice and the County of Flanders, France, Germany and the Balkans. Ports of the Black Sea have opened the way to China and Syria, of Alexandria - to India. Advantages of Venice as the intellectual centre and driving economy of that era, except the high technology of shipbuilding, were institutional innovation - the development of finance and banking, accounting, foreign exchange, credit markets, and diplomatic affairs. Portugal took over the leadership in the second half of the fifteenth century with the fall of The Byzantine Empire, the mighty of Ottoman Empire and a number of other factors, opening the way to the Indian Ocean, Japan, China, Brazil and America. During 1500-1820 more than half of African slaves were brought to America by the Portuguese. The Netherlands became an economic phenomenon of the sixteenth century. International specialisation has played a key role in the economic development of the Netherlands, which from 1400 to 1650 was the most powerful country in Europe. In 1700, only $40 \%$ of the workforce of the Netherlands was involved in agriculture. Flanders and Brabant were the most prosperous industrial areas in Europe, bringing the centre of banking and financial system and international trade. The sixteenth century is characterised by new dominants in the economic arena in Europe Britain and France, as the volume of foreign trade of the Netherlands fell by $20 \%$ in the period from 1720 to 1820, while exports in UK increased 7 times, and in France - more than 2 times. From 1720 to 1820, the GDP per capita of the Netherlands decreased 7 times, while in Britain and France it increased by 0.5 and 0.25 respectively. The reason for the rapid growth of the British income was the improvement of banking, financial and agricultural areas, as well as fiscal institutions. With the end of the Napoleonic Wars, the distribution of colonial powers in Europe varies: the Netherlands lose Asian territories (except Indonesia), France looses the Caribbean and Asia, Spain forfeits Latin America, retaining only Cuba, Puerto Rico and the Philippines, Brazil gains independence. Great Britain takes over the French and Dutch territories in Africa and Asia, expanding control over India and Latin America. Economic development of the UK played a significant role at that time, because it was not only characterised by technical progress or improvement of educational and qualification level of the workforce, but also by changes in trade policy: in 1846 the import duty on agricultural products was lifted, and in 1849 the Navigation Act, under which all goods received in England could only be carried by British ships or ships from the country of origin, ceased to have effect. By 1860, all trade and tariff restrictions were removed, which means that the free trade policy of England provided free sales of their goods abroad as well as cheap imported raw materials and food [11]. In the process of integration of the national markets of the twentieth century, the leading role was played by innovation in communications and the rule of the gold standard in the international payment system [12]. The beginning of the twentieth century defines Britain as the world's most powerful country with a population of 440 million, of which only 46 million accounts in the United Kingdom and England - all the rest were colonies (393.5 
million) [9]. As a result, the colonial factor becomes the foundation for the formation of international division of labour, which means the consolidation by the most developed countries of their monopolistic rights to produce major groups of manufactured goods and the concentration of export-oriented goods in colonial territories to meet the needs of their national economies in agriculture and raw materials [12] (Table 2).

Table 2. The level of GDP per capita of metropolises and former colonial countries during 1500-1998 (1990 international dollars)

\begin{tabular}{|l|c|c|c|c|c|c|}
\hline & $\mathbf{1 5 0 0}$ & $\mathbf{1 7 0 0}$ & $\mathbf{1 8 2 0}$ & $\mathbf{1 9 1 3}$ & $\mathbf{1 9 5 0}$ & $\mathbf{1 9 9 8}$ \\
\hline Great Britain & 762 & 1405 & 2121 & 5159 & 6907 & 18714 \\
\hline France & 727 & 986 & 1230 & 3485 & 5270 & 19558 \\
\hline Italy & 1100 & 1100 & 1117 & 2564 & 3502 & 17759 \\
\hline The Netherlands & 754 & 2110 & 1821 & 4049 & 5996 & 20224 \\
\hline Portugal & 632 & 854 & 963 & 1244 & 2069 & 12929 \\
\hline Spain & 698 & 900 & 1063 & 2255 & 2397 & 14227 \\
\hline \multicolumn{7}{|l|}{} \\
\hline China & 600 & 600 & 600 & 552 & 439 & 3117 \\
\hline India & 550 & 550 & 533 & 673 & 619 & 1746 \\
\hline Indonesia & 565 & 580 & 612 & 904 & 840 & 3070 \\
\hline Brazil & 400 & 560 & 646 & 811 & 1672 & 5459 \\
\hline Mexico & 425 & 568 & 759 & 1732 & 2365 & 6655 \\
\hline
\end{tabular}

Source [11].

\section{The Twentieth Century}

Thus, the modern European colonial expansion began in the late fifteenth century and by 1800 the Western powers, namely Great Britain, Holland, France, Spain and Portugal were concentrating 35\% of the Earth's surface in their hands and by 1878 they had $65 \%$ (Table 3). At the beginning of the twentieth century, colonial possessions spared only few countries of the world [6]. Between 1913 and 1950, the growth rate of the global economy was much slower than during 1870-1913. Global inequality increased dramatically. The First and the Second World Wars, the Great Depression of 1929-1930 and the Cold War had a devastating impact on international economic relations in general, because GDP per capita increased only by $38.5 \%$ from $1524 \$$ to $2111 \$$., considering the fact that during the Golden Era of 1870-1913, the growth rate was 75\%. The course of events of the First World War changed the direction and distribution of forces in the world, strengthening the position of the United States and Japan as the world's most powerful maritime states, leaving Britain behind. The main task and challenge was to return to the gold standard and revival of international capital flows and trade. The United States entered the war as the world's largest debtor, leaving it as the largest creditor, while high tariffs made it difficult to pay off debts for Europeans. There was a crisis of overproduction in agriculture, which led to low prices over the next 10 years. Hyperinflation in Germany destroyed the middle class, resulting in a sharp political situation which led to the Nazis 
coming to power. The Great Depression had a devastating impact on the global financial system, and the global market recovered to the level of 1929 only in 25 years - in 1954 [3]. During 1954-1969, 54 countries gained independence. During 1950-1973, the world economy grew faster than ever, characterised by annual growth of GDP per capita, GDP and trade volumes by $3 \%, 5 \%$ and $8 \%$ respectively.

The proponents of the structuralist theory claim that the current state of global economic development cannot be considered out of colonial legacy, which distributes commercial, technological and financial benefits between countries.

Table 3. Share of world GDP of some regions and countries between 1000 and 1998 (\%)

\begin{tabular}{|l|c|c|c|c|c|c|c|c|c|c|}
\hline & $\mathbf{1 0 0 0}$ & $\mathbf{1 5 0 0}$ & $\mathbf{1 6 0 0}$ & $\mathbf{1 7 0 0}$ & $\mathbf{1 8 2 0}$ & $\mathbf{1 8 7 0}$ & $\mathbf{1 9 1 3}$ & $\mathbf{1 9 5 0}$ & $\mathbf{1 9 7 3}$ & $\mathbf{1 9 9 8}$ \\
\hline Austria & - & 0.6 & 0.6 & 0.7 & 0.6 & 0.8 & 0.9 & 0.5 & 0.5 & 0.5 \\
\hline Belgium & - & 0.5 & 0.5 & 0.6 & 0.7 & 1.2 & 1.2 & 0.9 & 0.7 & 0.6 \\
\hline Denmark & - & 0.2 & 0.2 & 0.2 & 0.2 & 0.3 & 0.4 & 0.6 & 0.4 & 0.3 \\
\hline Finland & - & 0.1 & 0.1 & 0.1 & 0.1 & 0.2 & 0.2 & 0.3 & 0.3 & 0.3 \\
\hline France & - & 4.4 & 4.7 & 5.7 & 5.5 & 6.5 & 5.3 & 4.1 & 4.3 & 3.4 \\
\hline Germany & - & 3.3 & 3.8 & 3.6 & 3.8 & 6.5 & 8.8 & 5.0 & 5.9 & 4.3 \\
\hline Italy & - & 4.7 & 4.4 & 3.9 & 3.2 & 3.8 & 3.5 & 3.1 & 3.6 & 3.0 \\
\hline Holland & - & 0.3 & 0.6 & 1.1 & 0.6 & 0.9 & 0.9 & 1.1 & 1.1 & 0.9 \\
\hline Norway & - & 0.1 & 0.1 & 0.1 & 0.2 & 0.2 & 0.2 & 0.3 & 0.3 & 0.3 \\
\hline Sweden & - & 1.2 & 0.2 & 0.3 & 0.4 & 0.6 & 0.6 & 0.9 & 0.7 & 0.5 \\
\hline Switzerland & - & 0.1 & 0.2 & 0.3 & 0.3 & 0.5 & 0.6 & 0.8 & 0.7 & 0.5 \\
\hline GB & - & 1.1 & 0.1 & 2.9 & 5.2 & 9.1 & 8.3 & 6.5 & 4.2 & 3.3 \\
\hline 12 countries together & - & 15.5 & 17.2 & 19.5 & 20.9 & 30.7 & 31.1 & 24.1 & 22.8 & 17.9 \\
\hline Portugal & - & 0.3 & 0.3 & 0.5 & 0.5 & 0.4 & 0.3 & 0.3 & 0.4 & 0.4 \\
\hline Spain & - & 1.9 & 2.1 & 2.2 & 1.9 & 2.0 & 1.7 & 1.3 & 1.9 & 1.7 \\
\hline West Europe & 8.7 & 19.9 & 19.9 & 22.5 & 23.6 & 33.6 & 33.5 & 26.3 & 25.7 & 20.6 \\
\hline East Europe & 2.2 & 2.5 & 2.7 & 2.9 & 3.3 & 4.1 & 4.5 & 3.5 & 3.4 & 2.0 \\
\hline USSR \\
(former countries) & 2.4 & 4.3 & 3.5 & 4.4 & 5.4 & 7.6 & 8.6 & 9.6 & 9.4 & 3.4 \\
\hline USA & & & & & & & & & & \\
\hline Mexico & - & 0.3 & 0.2 & 0.1 & 1.8 & 8.9 & 19.1 & 27.3 & 22.0 & 21.9 \\
\hline South America & - & 1.3 & 0.3 & 0.7 & 0.7 & 0.6 & 1.0 & 1.3 & 1.7 & 1.9 \\
\hline Japan & 3.9 & 2.9 & 1.1 & 1.7 & 2.0 & 2.5 & 4.5 & 7.9 & 8.7 & 6.7 \\
\hline China & 2.7 & 3.1 & 2.9 & 4.1 & 3.0 & 2.3 & 2.6 & 3.0 & 7.7 & 7.7 \\
\hline India & 22.7 & 25.4 & 29.2 & 22.3 & 32.9 & 17.2 & 8.9 & 4.5 & 4.6 & 11.5 \\
\hline Africa & 28.9 & 24.5 & 22.6 & 24.4 & 16.0 & 12.2 & 7.6 & 4.2 & 3.1 & 5.0 \\
\hline
\end{tabular}

Source [11].

The second half of the twentieth century marks a qualitatively new stage of economic development. It displays a new level of international competitive standards, which were the basis for rapid scientific and technological progress. The result was a new postindustrial society and the institutional and social direction of economic thought, where the role of human capital and high-tech goods become extremely important. The role of 
the United Nations established by 51 states on the basis of the Charter of United Nations in 1945 is growing rapidly, counting 156 member states in 1981. The "Golden Age" (19451970) of economic prosperity of the West finally separates the development of the world. The capitalist and the communist models of development shared the world, especially with the victory of the Communist Party of China in 1949, which meant the existence of $1 / 6$ of the population under the communist regime. The Marshall Plan, under which economic aid was provided to some countries of Western Europe (especially France and Italy, where the Communist Party had considerable support) in order to prevent the spread of socialist ideas, in fact, can be considered as the beginning of the Cold War.

International institutions were created to regulate and harmonise different aspects: the UN - to support peace, international security and cooperation among nations, the Bretton Woods system - to settle international monetary and financial relations after the Second World War and to coordinate principles of a new monetary system, GATT - to ensure equal and non-discriminatory trade regime and to reduce tariffs on the basis of multilateral agreements and eventually eliminate import quotas, the IMF - to regulate the monetary and credit relations between member states and help them with deficits through short and medium-term loans in foreign currency and the World Bank - to maintain economic stability. Despite the fact that the communist states are characterised by economic stagnation and lower level of development in comparison with the West, real poverty is mostly felt in the states that were former European colonies [6].

\section{Modern Realities}

Now developing countries are most acutely experiencing the negative effects of this phenomenon, as the prospect to achieve high level of social welfare of the West decreases, despite the fact that the concentration of raw resources in developing countries is quite high for rapid economic development [8].

As a result, the realities of modern global economic system outline the following: $86 \%$ of world consumption accounts for $20 \%$ of the population, where the total wealth of 225 the richest people (\$ 1 trillion) are equal to revenues of $47 \%$ of the world population (2.5 billion people). According to the forecasts of the UN Development Program, $4 \%$ of the income of the wealthiest people would provide sufficient access to education, health care, food, clean water and other vital resources for the population of developing countries.

For example, in 1989 1/5 of the richest population of the world got 59 times more revenue than $1 / 5$ of the poorest, $82.7 \%$ and $1.4 \%$ respectively. The third and fourth quantiles also remain at a low level $-2.3 \%$ and $1.9 \%$. Unfortunately, the global trend is getting worse every year. The ratio between $1 / 5$ of the richest and poorest population of the world is the following: in 1960 - 30:1, in $1990-60: 1,1997-74: 1$.

Yet, according to the World Bank estimates, during 1980 the total level of world poverty has reduced, because in 1981 the number of people living for less than 1 dollar per day significantly decreased, compared to 2007 -- 1,452 billion and 1.1 billion respectively. Poverty reduction occurred in South and East Asia, while in most countries of Africa, South and Central America, the poverty level increased or remained without significant changes [4] (Fig. 3). 
Fig. 3. Dynamics of the population in some regions of the world living in extreme poverty (less than $\$ 1.08$ per day) during 1981-2001 (millions of persons)

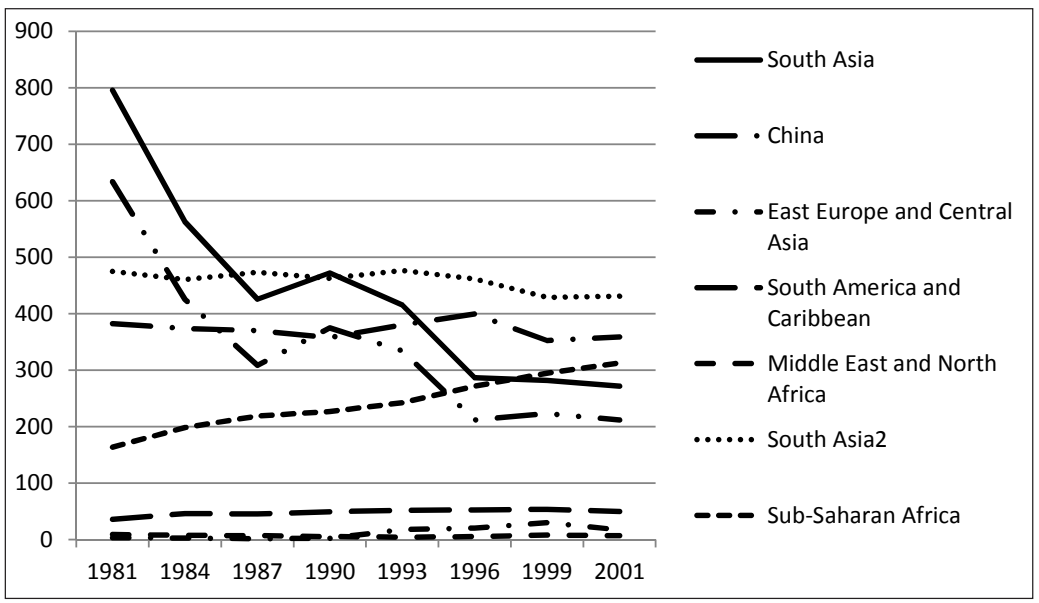

Source [2].

According to the Population Reference Bureau, which has monitored a variety of statistical data, in $2011,48 \%$ of the population lived for less than $2 \$$ per day. The fact of asymmetry of global economic development is obvious.

\section{Conclusion}

Therefore, in our opinion, the origins of uneven economic development of the world stem from the period of colonialism. The period between the sixteenth and twentieth centuries was defined as metropolitan dominance over the rest of the world and economic exploitation on the metropolitan benefits. Respectively, the main cause of the present-day extremely asymmetric economic model is colonial, as capital was accumulated in the hands of metropolises, which meant unequal distribution of power and interests at international level, monopolisation of world trade and access to raw materials, which was manifested in the exploitation of human and natural resources. The consequences of colonialism are felt not only in economic, but also in political, social, ethnic, religious, cultural and others spheres, as shown on the modern map through the prism of uneven economic division of the world.

The second reason is the Industrial Revolution of the nineteenth century in Europe, USA and Japan, which led to the hierarchical distribution of benefits of economic progress, by forming industrialised and dependent countries. As a consequence of the emergence of capitalist relations and the use of scientific knowledge in production, technogenic development established a modern manifestation of international economic relations through the prism of "center-periphery".

We also believe that an integrated global economic system, constituted under the influence of globalisation, is very unevenly distributed in the geographical framework. 
International trade, which results in international division of labour and world market, is now more "local" than global. Thus, $2 / 3$ of trade flows are concentrated in Western Europe between the European powers. Similar indicators exist between Asia and North America $50 \%$ and $40 \%$ respectively [10]. Global experience shows that economic ties between those three aforementioned regions of the world are intense, violating the proportionality between the other regions, leaving Africa, the Middle East, Eastern Europe and other regions behind.

Figure 4. Cause-and-effect Ishikawa diagram of the problem of uneven economic development of the world economy

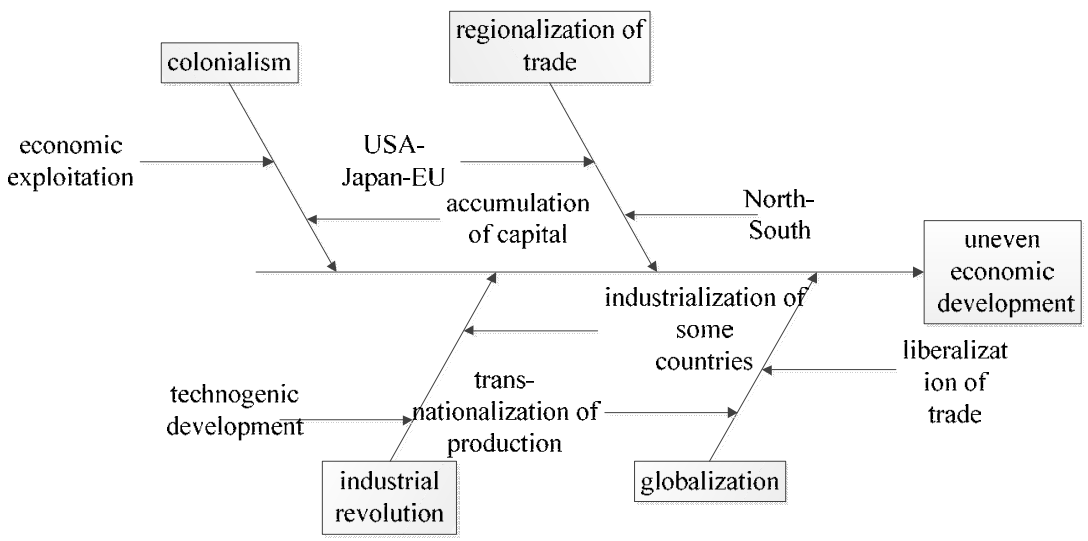

Thus, the exchange of goods, services and capital between countries is based on the interaction of modern globalised world economy. Such integration is manifested in all spheres of public life, characterised by reciprocity and dependence on one side and asymmetric access to global markets, on the other. International experience demonstrates that examination of the unevenness problem only from an economic perspective is insufficient, as the political and social factors are also in the interaction, forming current trends of the global economy as a state and a process. Retrospective analysis of the problem of uneven economic development shows that the fall of the colonial system led to a line of independent countries that later formed the group of "Third World countries" and the post-war transformation strengthened the division of the world into capitalist and socialist camps, which caused political and economic polarisation and confrontation of the world. This resistance means increased socio-economic and trade isolation and military power that divide the world into current economic zones and blocks.

\section{References}

1. Bourguignon, F., Morrisson C. (2002) "Inequality among World Citizens: 18201992" The American Economic Review Vol. 92, No. 4, 27-744 p. 
2. Chen S., Ravallion M. (1999) "How Did the World's Poorest Fare in the 1990s?" The World Bank, $30 \mathrm{p}$.

3. Eckes, A.(2011) “The contemporary global economy: a history since 1980", Library of Congress Catalog-in-Publishing Data

4. Glenn, J. (2007) “Globalization: North-South perspective Routledge”, p. 155-157

5. Goldin, I., Reineert K. (2006) "Globalization for development: trade finance, aid, migration and policy" The World Bank, p. 23

6. Greig, A., Hulme D., Turner M. (2007) "Challenging Global Inequality: Development Theory and Practice in the $21^{\text {st }}$ Century", Palgrave Macmillan, p. 59

7. Kyrylych, Kh. (2012) "Uneven economic development in the context of post-colonialism: economic cooperation between the EU and ACP countries" Modernization strategies for economic development in terms global instability, International Scientific Conference, Kyiv, 22-23 November, 2012

8. Kyrylych, Kh. (2012) "Uneven economic development of the world as a global problem" The strategy of economic development of countries in terms of globalization, Materials of III Internat. Science Scient. Conf. of young scientists and students, 1718 February 2012. : Vol. 5 - Dnepropetrovsk: Bila K. O

9. Levinsky, B. (1916) "Cause of World War II (on imperialism)" Scranton: Narodna Volja, 24 p.

10. Mackinnon, D., Cumbers A. (2007) "An Introduction to Economic Geography: Globalization, Uneven Development and Place” Prentice Hall; 1 edition, p. 376

11. Meddison, A. (2001) "The world economy: a millennium perspective" Organisation for Economic Co-operation and Development (OECD), p. 385

12. Stolyarchuk, Ja. (2009) "Global asymmetry of economic development" Kyiv National Economic University, p. 302

\section{PASAULIO EKONOMIKOS NETOLYGIOS RAIDOS PROBLEMA: ESME் IR PRIEŽASTYS}

Santrauka. Straipsnyje nagrinejjama netolygi ekonomikos plètra globalizacijos ir integracijos procese ir analizuojami dabartiniai aspektai bei perspektyvos. Retrospektyvine problemos analize siekiama atskleisti netolygaus pasaulio vystymosi priežastis. Remiantis analizès rezultatais vertinama dabartinè pasaulio ekonomikos būklè ir bandoma atsakyti ị klausimą, kodèl kai kurios šalys yra turtingos, o kai kurios - neturtingos. Straipsnyje pabrě̌̌iama, kad kolonializmo padariniai yra viena pagrindinių netolygios pasaulio šalių ekonominės raidos priežasčių. Industrinės revoliucijos, globalizacija ir prekybos regionalizacija turejo ženklios įtakos pasaulio suskirstymui ị „Šiaurę" ir „Pietus“.

Khrystyna KYRYLYCH - PhD student, Department of International Relations, Ivan Franko National University of Lviv, Ukraine. Research fields: uneven economic development.

Khrystyna KYRYLYCH - Lvovo nacionalinio Ivano Franko universiteto Tarptautinių ryšių skyrius, doktorantè. Mokslinių tyrimų sritis: netolygi ekonomikos plètra. 